\title{
Inhibitory Effect of Glucagon-like Peptide-1 on Small Bowel Motility Fasting but not Fed Motility Inhibited via Nitric Oxide Independently of Insulin and Somatostatin
}

\author{
Tesfaye Tolessa, ${ }^{\star}$ Mark Gutniak, ${ }^{\ddagger}$ Jens Juul Holst, ${ }^{\S}$ Suad Efendic, ${ }^{\ddagger}$ and Per M. Hellström \\ *Department of Medicine, ${ }^{\ddagger}$ Department of Endocrinology and Metabolism, Karolinska Hospital, Karolinska Institute, SE-171 76 \\ Stockholm, Sweden; and ${ }^{\S}$ Department of Medical Physiology, Panum Institute, DK-2100 Copenhagen, Denmark
}

\begin{abstract}
Effects of glucagon-like peptide-1 (GLP-1)(7-36)amide on fasted and fed motility in the rat small intestine were investigated in relation to its dependence on nitric oxide (NO), insulin, and somatostatin. Small bowel electromyography was performed using bipolar electrodes implanted 15, 25, and $35 \mathrm{~cm}$ distal to pylorus, and transit was studied with a radioactive marker. In the fasted state, GLP-1 (5-20 pmol $\mathrm{kg}^{-1} \mathrm{~min}^{-1}$ ), reaching physiological plasma levels, prolonged the migrating myoelectric complex (MMC) cycle length along with slowed transit. This effect was antagonized by exendin(9-39)amide. The NO synthase inhibitor $\mathrm{N}^{\omega}$-nitroL-arginine (L-NNA) also blocked the response to GLP-1, whereas L-arginine restored the response. Insulin (80-200 pmol kg ${ }^{-1} \mathrm{~min}^{-1}$ ) induced irregular spiking, whereas somatostatin (100-500 $\mathrm{pmol} \mathrm{kg}^{-1} \mathrm{~min}^{-1}$ ) increased the MMC cycle length, independently of NO. In the fed state, GLP-1 (20-40 pmol $\mathrm{kg}^{-1} \mathrm{~min}^{-1}$ ) reduced motility, an inhibition unaffected by L-NNA, whereas motility was stimulated by exendin(9-39)amide. Infusion of GLP-1 (20-100 pmol $\mathrm{kg}^{-1} \mathrm{~min}^{-1}$ ) did not affect plasma insulin, but somatostatin was increased.

In conclusion, GLP-1 seems to inhibit small bowel motility directly via the GLP-1 receptor. Inhibition of fasting motility is dependent of $\mathrm{NO}$ and not mediated via insulin or somatostatin, whereas inhibition of fed motility is independent of NO. (J. Clin. Invest. 1998. 102:764-774.) Key words: gastrointestinal motility • glucagon-like peptide-1 1 migrating myoelectric complex $\bullet$ rat $\bullet$ small intestine
\end{abstract}

\section{Introduction}

The gene-encoding glucagon is expressed both in the intestine and in the pancreas $(1,2)$. The 160 -amino acid glucagon precursor is processed differently in the intestine than in the pancreas $(1,3)$. In pancreatic alpha cells the main processing products are glicentin-related pancreatic polypeptide, glucagon, and a major proglucagon fragment $(1,3-5)$. In L-cells of the small intestine, the main products are glicentin, which may be cleaved further to glicentin-related pancreatic polypeptide and

Address correspondence to Per M. Hellström, Section of Gastroenterology, Department of Medicine, Karolinska Hospital, SE-171 76 Stockholm, Sweden. Phone: 468 5177-3877; FAX: 468 5177-2058; E-mail: Per.Hellstrom@medks.ki.se

Received for publication 16 June 1997 and accepted in revised form 11 June 1998.

J. Clin. Invest.

(c) The American Society for Clinical Investigation, Inc. 0021-9738/98/08/0764/11 \$2.00

Volume 102, Number 4, August 1998, 764-774

http://www.jci.org oxyntomodulin plus the two glucagon-related peptides, glucagon-like peptide-1(7-36)amide (GLP-1) $)^{1}$ and glucagon-like peptide-2 (1, 3-6).

Accumulating evidence show that one of the intestinal products, GLP-1, stimulates insulin secretion, inhibits glucagon secretion, and enhances insulin sensitivity with great impact on glucose metabolism (6-9). In other studies on isolated rat pancreatic cells, GLP-1 has also been found to stimulate somatostatin secretion (10). Recent findings in man show that GLP-1 at physiological plasma concentrations is able to inhibit gastric emptying rate $(11,12)$, a mechanism that may further influence postprandial glucose metabolism. It is likely that effects on both hormonal responses and gastric emptying participate in the marked antidiabetogenic effect of GLP-1.

So far, the effect of the GLP-1 on motility of the small intestine has not been studied. The purpose of this study was to investigate the effects of GLP-1 on the small intestinal motor pattern in the fasted, as well as the fed state, using the GLP-1 receptor antagonist exendin(9-39)amide. Because the motor responses to the peptide was of an inhibitory kind, the possible involvement of nitric oxide (NO) in its action on motility was investigated. Furthermore, the distinct possibility that the marked inhibitory effect of GLP-1 on motility is mediated by released insulin and somatostatin was studied.

\section{Methods}

107 male Sprague-Dawley rats (B\&K, Sollentuna, Sweden) weighing 300-350 g were used for the study. The experimental protocol was approved by the local Ethics committee for animal experimentation in northern Stockholm, Sweden.

Preparation of rats for electromyography. 53 rats were anaesthetized with pentobarbital (50 mg kg-1 intraperitoneally; Apoteksbolaget, Umeå, Sweden) and, through a midline incision, three bipolar stainless steel electrodes (SS-5T, Clark Electromedical Instruments, Reading, UK) were implanted into the muscular wall of the small intestine $15(\mathrm{~J} 1), 25(\mathrm{~J} 2)$, and $35(\mathrm{~J} 3) \mathrm{cm}$ distal to the pylorus. All animals were supplied with one or two jugular vein catheters for administration of drugs. The electrodes and catheters were tunneled subcutaneously to exit at the back of the animal's neck. After surgery the animals were housed singly and allowed to recover for at least $7 \mathrm{~d}$ before experiments were undertaken. During recovery the rats were trained to accept experimental conditions. Experiments were then carried out in conscious animals after an 8-h fasting period in wirebottomed cages with free access to water. During the experiments, the rats were placed in Bollman cages. The electrodes were connected to an EEG preamplifier (7P5B) operating a Grass Polygraph 7B (Grass Instruments, Quincy, MA). The time constant was set at $0.015 \mathrm{~s}$ and the low and high cut-off frequencies were set at 10 and 35 $\mathrm{Hz}$, respectively.

1. Abbreviations used in this paper: GLP-1, glucagon-like peptide-1(736)amide; L-NNA, $\mathrm{N}^{\omega}$-nitro-L-arginine; MMC, migrating myoelectric complex; $\mathrm{NO}$, nitric oxide. 
Design of electromyography studies. All experiments started with a control recording of basal myoelectric activity with four activity fronts propagated over all three recording sites during a period of $\sim 60$ min.

In experiments with fasted motility pattern, the infusion of GLP-1, insulin, or somatostatin was started immediately after the fifth activity front had passed the first electrode site using a microinjection pump (CMA 100, Carnegie Medicine, Stockholm, Sweden). Similarly, in experiments with exendin(9-39)amide to antagonize the effect of GLP-1, the antagonist was administered after the fifth activity front followed later by a parallel infusion of GLP-1.

In a first series of experiments, GLP-1 at doses of 1-20 pmol $\mathrm{kg}^{-1} \min ^{-1}$ was administered intravenously for $60 \min (n=7)$.

A second series of experiments was carried out with an intravenous infusion of exendin(9-39)amide at a dose of 1,000 pmol $\mathrm{kg}^{-1} \mathrm{~min}^{-1}$ starting $15 \mathrm{~min}$ before commencement of infusion of GLP-1 at a dose of $10 \mathrm{pmol} \mathrm{kg}^{-1} \mathrm{~min}^{-1}$ for $60 \min (n=6)$.

A third series of experiments was performed with intravenous infusions of insulin at doses of 40-200 $\mathrm{pmol} \mathrm{kg}^{-1} \mathrm{~min}^{-1}$ during $60 \mathrm{~min}$ $(n=7)$. In a fourth series, somatostatin at $50-500 \mathrm{pmol} \mathrm{kg}^{-1} \mathrm{~min}^{-1}$ was administered intravenously for an equal period $(n=7)$.

In a fifth series of experiments, the effect of the nitric oxide synthase inhibitor $\mathrm{N}^{\omega}$-nitro-L-arginine (L-NNA) was studied on the response to GLP-1 $(n=6)$. After a 1-h control period, GLP-1 alone was given intravenously at a dose of $10 \mathrm{pmol} \mathrm{kg}^{-1} \mathrm{~min}^{-1}$. L-NNA, at a dose of $1 \mathrm{mg} \mathrm{kg}^{-1}$, was then administered intravenously $10 \mathrm{~min}$ before the administration of GLP-1 was repeated. Subsequently, further treatment with L-arginine $300 \mathrm{mg} \mathrm{kg}^{-1}$ was given before another infusion of GLP-1.

In a sixth series, the effect of L-NNA on the response to somatostatin was evaluated $(n=8)$. Similarly, after a 1 -h control period, somatostatin was administered intravenously at $500 \mathrm{pmol} \mathrm{kg}^{-1} \mathrm{~min}^{-1}$ for $60 \mathrm{~min}$. Then, L-NNA at a dose of $1 \mathrm{mg} \mathrm{kg}^{-1}$ was given intravenously and the administration of somatostatin was repeated within 10 min.

In experiments with fed motility pattern, experiments were performed by feeding the rats 4-5 $\mathrm{g}$ of a cookie (McVitie's Hob-nobs, United Biscuits, Göteborg, Sweden) after the fifth activity front had disappeared at the first electrode site. This feeding procedure disrupted the migrating myoelectric complex (MMC) and induced irregular spiking as typically seen after food intake.

In a seventh series of experiments, GLP-1 at a dose of 5-40 pmol $\mathrm{kg}^{-1} \mathrm{~min}^{-1}$ was administered intravenously $15 \mathrm{~min}$ before food intake. The motility response to food after pretreatment with GLP-1 was compared to that without the peptide in the same animals $(n=8)$.

In an eighth series exendin(9-39)amide at a dose of 1,000 pmol $\mathrm{kg}^{-1} \mathrm{~min}^{-1}$ was administered intravenously $15 \mathrm{~min}$ before food intake. The motility response to food after pretreatment with exendin(939)amide was compared to the response without the compound in the same animals $(n=6)$

In a ninth series of experiments, the effect of L-NNA was studied on the response to GLP-1 in the fed state. L-NNA at a dose of $1 \mathrm{mg}$ $\mathrm{kg}^{-1}$ was first administered intravenously, followed 10 min later by GLP-1 at 20 pmol kg-1 $\mathrm{min}^{-1}$. After $15 \mathrm{~min}$, GLP-1 food was given and the postprandial motility response to GLP-1 after pretreatment with L-NNA was compared to that without L-NNA in the same animals $(n=6)$.

Preparation of rats for small bowel transit studies. 23 rats, previously provided with three bipolar electrodes and a jugular vein catheter for administration of drugs, were again anesthetized with pentobarbital (50 mg kg-1 intraperitoneally). Through an abdominal midline incision, an indwelling polyethylene catheter (PE 50, Clay Adams, Becton Dickinson and Co., Parsippany, NJ) was implanted into the duodenum $1 \mathrm{~cm}$ distal to the first electrode site for administration of a radioactive marker solution. The catheter was tunneled subcutaneously to exit at the back of the animal's neck. After surgery, the animals were allowed to recover for at least $3 \mathrm{~d}$ before experiments were undertaken. Experiments were carried out with fasted motility after a fasting period of $8 \mathrm{~h}$ and performed on conscious animals in Bollman cages.

Design of studies. Immediately after an activity front of MMC had vanished from the first electrode site, an infusion of saline or GLP-1 was started and $0.4 \mathrm{ml}$ of a radioactive transit marker solution consisting of polyethylene glycol 4000 containing $1.48 \mathrm{MBq} \mathrm{ml}^{-1}$ of $\mathrm{Na}_{2}{ }^{51} \mathrm{CrO}_{4}\left(\mathrm{pH} 7.2,300 \mathrm{mOsm} \mathrm{kg}{ }^{-1}\right.$ ) was administered slowly over a period of $30 \mathrm{~s}$ into the duodenum. After $60 \mathrm{~min}$ of infusion, the rats were then killed with an overdose of pentobarbital. The abdomen was opened, the gastrointestinal tract ligated at multiple points, and carefully removed in toto.

In a first series of experiments, saline was administered intravenously as control $(n=9)$. In a second and third series, GLP-1 was administered intravenously at doses $10(n=8)$ or $20(n=6)$ pmol $\mathrm{kg}^{-1} \min ^{-1}$.

Preparation of rats for hormone release studies. 44 rats were kept under anesthesia using pentobarbital $\left(50 \mathrm{mg} \mathrm{kg}^{-1}\right.$ intraperitoneally) and supplied with a jugular vein catheter for administration of saline or peptides. After surgery, the rats were allowed to recover.

Design of hormone release studies. In conscious animals, continuous infusions of different peptides were carried out for $30 \mathrm{~min}$. Thereafter, blood samples of $5 \mathrm{ml}$ were obtained by heart puncture under pentobarbital sedation. Blood samples were collected using heparinized Vacutainer ${ }^{\circledR}$ tubes (Becton Dickinson, Meylan Cedex, France) and centrifuged at 3,000 rpm for $10 \mathrm{~min}$. The plasma was pipetted off and stored in $-70^{\circ} \mathrm{C}$.

In a first series of experiments, saline $(n=6)$ was given, whereas in a second and third series, GLP-1 at doses of $20(n=6)$ or $100(n=$ 6) $\mathrm{pmol} \mathrm{kg} \mathrm{min}^{-1}$ were infused intravenously to analyze the plasma concentrations of GLP-1, insulin, and somatostatin attained with these treatments, as well as circulating blood glucose levels.

In a fourth series of experiments, insulin $80 \mathrm{pmol} \mathrm{kg}^{-1} \mathrm{~min}^{-1}(n=6)$, and in a fifth series, somatostatin $100 \mathrm{pmol} \mathrm{kg}{ }^{-1} \min ^{-1}(n=6)$, were given intravenously to measure the plasma concentrations of insulin and somatostatin attained at these infusion rates. The doses of insulin and somatostatin were chosen, as they were the lowest ones affecting motility.

In a sixth series, the circulating levels of GLP-1 in response to feeding were analyzed. The conscious animals were fed $4-5 \mathrm{~g}$ of a cookie during a $30-\mathrm{min}$ period. The rats were then anesthetized with pentobarbital sodium through the intravenous catheter and blood samples were obtained by heart puncture using heparinized tubes, as described above $(n=6)$.

In a seventh series, fasting plasma values of GLP-1 were obtained from a comparable group of rats that were deprived of food, studied for an equal time period, and killed in a similar manner $(n=8)$.

Assays. Immunoreactive insulin was measured by radioimmunoassay using antibodies against porcine insulin, raised in guinea pig and ${ }^{125}$ I-labeled porcine insulin as tracer. Antibodies were incubated with samples before adding the labeled hormone. Rat insulin (Novo Nordisk, Bagsværd, Denmark) was used as a standard. The sensitivity of the assay was $\sim 1 \mathrm{pmol}^{-1}$, and the sample volume $50 \mu \mathrm{l}$. Dextrancoated charcoal was used to separate bound from free insulin. Intraand interassay coefficients of variation were 5 and $10 \%$, respectively. The cross-reactivity with proinsulin was $\sim 100 \%$. There was no crossreactivity between C-peptide and insulin in the assay (13).

Immunoreactive somatostatin was analyzed with radioimmunoassay as described previously. The detection limit was $2 \mathrm{pmol}^{-1}$, and the intra- and interassay coefficients of variation were 7 and $11 \%$, respectively (14).

The plasma concentrations of immunoreactive GLP-1 were measured as previously described (15) against standards of GLP-1 using antiserum 89390 raised against synthetic proglucagon 78-107 amide. This antiserum has an absolute requirement for the intact amidated C-terminal of GLP- 1 and cross-reacts $<0.01 \%$ with C-terminally truncated or extended forms. The detection limit of the assay is $1 \mathrm{pmol}^{-1}$ and the intra-assay coefficient of variation $5 \%$ at $20 \mathrm{pmol}$ $1^{-1}$. Before radioimmunoassay of GLP-1, plasma was extracted with ethanol as described (16). 


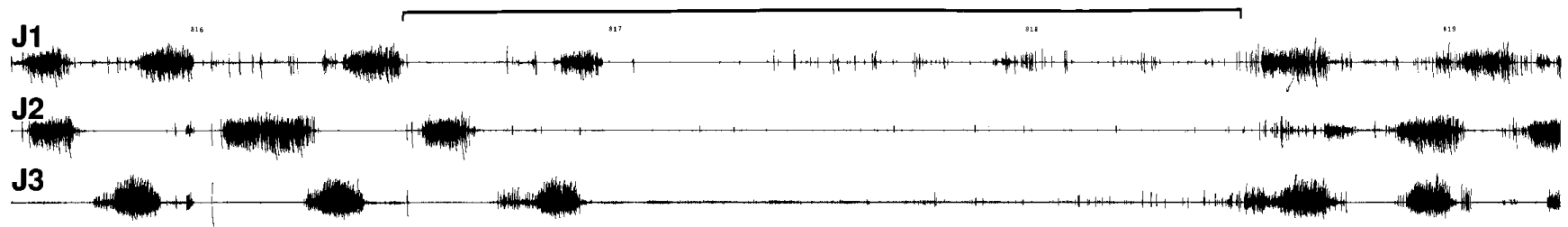

$[0.25 \mathrm{mV}$

$10 \mathrm{~min}$

Figure 1. Electromyographic recording from the rat jejunum at 15 (J1), 25 (J2), and 35 (J3) cm distal to the pylorus showing the effect of GLP-1 on the MMC.

Blood glucose concentrations were measured with a glucose oxidase method (17).

Drugs and chemicals. GLP-1 was purchased from Saxon Biochemicals GmbH (Hannover, Germany). Exendin(9-39)amide and somatostatin were purchased from Peninsula Laboratories Ltd. (Merseyside, UK), whereas L-NNA and L-arginine was obtained from Sigma Chemical Co. (St. Louis, MO). Insulin (Actrapid ${ }^{\mathrm{TM}}$ ) was obtained from Novo Nordisk (Bagsvaerd, Denmark). The radioactive marker, $\mathrm{Na}_{2}{ }^{51} \mathrm{CrO}_{4}$, was purchased from Amersham (Buckinghamshire, UK). Saline solution (Natriumklorid $154 \mathrm{mmol} \mathrm{l}^{-1}$, Baxter Medical AB, Kista, Sweden) was used for control infusions and for dilution of peptides and drugs.

Data processing and statistical analysis. The main characteristic feature of myoelectric activity of the small intestine in the fasted state, the activity front, or phase III of MMC, was identified as a period of clearly distinguishable intense spiking activity with an amplitude at least twice that of the preceding baseline, propagating aborally through the whole recording segment and followed by a period of quiescence, phase I of MMC. Phase II of MMC was characterized as a period of irregular spiking preceding the activity front. Prolonged periods of $>30 \mathrm{~min}$ with scattered spike potentials, but no discernible cyclic activity, were considered as periods of disrupted MMC activity. Periods with no detectable spike potentials were considered as quiescence. Calculations of characteristics of MMC, such as the MMC cycle length, and the duration, propagation velocity, and calculated length of phase III were accomplished using a recently developed computer program $(18,19)$, which permits a detailed descriptive analysis of the MMC.

Small bowel transit was computed as the geometric center for the distribution of the radioactive marker along the gut. The small intestine was divided into 10 segments of equal size and their content of radioactive marker was measured in a gamma counter (Compucount, Beckman, Fullerton, CA). The geometric center for the distribution of the radioactive marker was calculated as the relative amount of the radioactive marker in each segment multiplied by the individual number of each segment (starting from the pylorus) and added to obtain the geometric center for the distribution of the marker in the small intestine $(20,21)$.

Experiments in the fed state were carried out with computerized recordings of the spiking activity with a sampling frequency of $200 \mathrm{~Hz}$ and a cut-off level of $5 \%$ as described previously (19). In brief, intestinal spiking activity at all electrode sites was recorded for $10 \mathrm{~min}$, beginning $30 \mathrm{~min}$ after start of food intake. The spiking activity was computed and expressed as number of spikes per $10 \mathrm{~s}$.

Data are expressed as means and $95 \%$ confidence interval within parenthesis of $n$ experiments. Data were statistically compared as repeated measures using ANOVA followed by Bonferroni after test or paired observations using Student's $t$ test where appropriate. $P<0.05$ in two-tailed tests was considered statistically significant.

\section{Results}

Studies of the fasted motor pattern

Under fasting conditions, all rats exhibited a fasted motor pattern with recurring MMCs that were propagated through the intestinal segment under study.

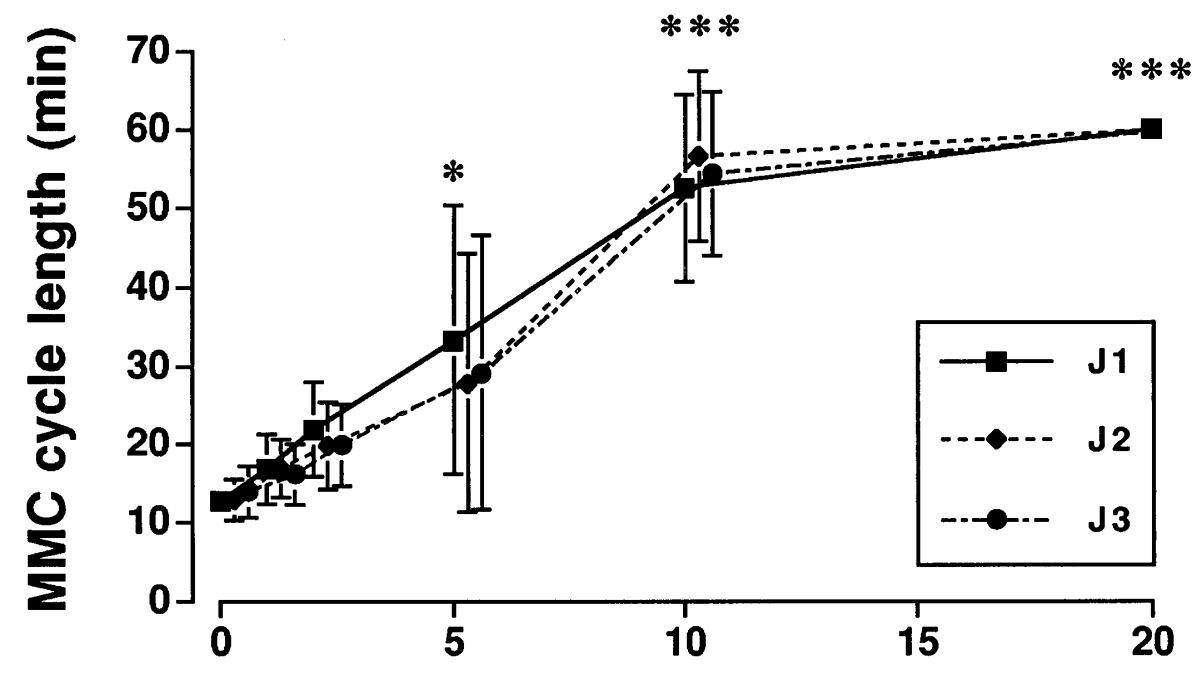

Glucagon-like peptide-1 (pmol kg-1 $\left.\mathrm{min}^{-1}\right)$
Figure 2. Dose-response curve showing the effect of increasing intravenous doses of GLP-1 on the cycle length of the MMC at three different levels in the rat jejunum, 15 (J1), 25 (J2), and 35 (J3) cm distal to the pylorus. Mean values and $95 \%$ confidence interval $(n=7) . * P<0.05, * * * P<0.001$. 


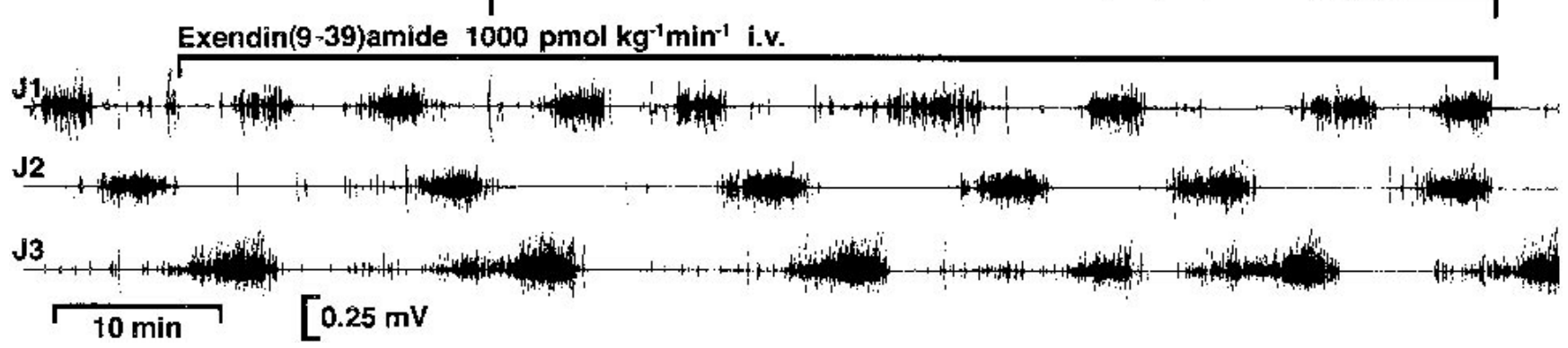

Figure 3. Electromyographic recordings of the MMC propagated through the rat jejunum at 15 (J1), 25 (J2), and 35 (J3) cm distal to the pylorus. Effect of exendin(9-39)amide on the basal MMC pattern and inhibition of response to GLP-1 (see Fig. 1).

Effects of GLP-1 on MMC. Infusion of GLP-1 at doses of 10 and $20 \mathrm{pmol} \mathrm{kg} \mathrm{kg}^{-1} \mathrm{~min}^{-1}$ had an inhibitory effect on the

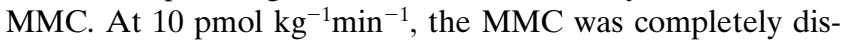
rupted during the infusion period $(P<0.05$; Fig. 1$)$. GLP-1 increased the MMC cycle length in a dose-dependent manner (Fig. 2). The characteristics of phase III in controls with a duration of $3.5 \pm 1.0,3.6 \pm 0.8$, and $3.5 \pm 0.5 \mathrm{~min}$ at the $\mathrm{J} 1, \mathrm{~J} 2$, and $\mathrm{J} 3$ sites of the jejunum, a propagation velocity of $1.7 \pm 1.1$ and
$1.5 \pm 0.7 \mathrm{~cm} \mathrm{~min}^{-1}$, as well as a calculated length of $6.2 \pm 4.2$ and $5.4 \pm 2.3$ min between the $\mathrm{J} 1$ and $\mathrm{J} 2$, as well as $\mathrm{J} 2$ and $\mathrm{J} 3$ sites, respectively, were not changed until motor quiescence was induced. During the infusions of GLP-1 the general condition of the animals was not affected.

Pretreatment of the rats with exendin(9-39)amide intravenously at a dose of $1,000 \mathrm{pmol} \mathrm{kg}{ }^{-1} \mathrm{~min}^{-1}$ completely antagonized the inhibitory effect of GLP-1 at $10 \mathrm{pmol} \mathrm{kg}^{-1} \mathrm{~min}^{-1}$
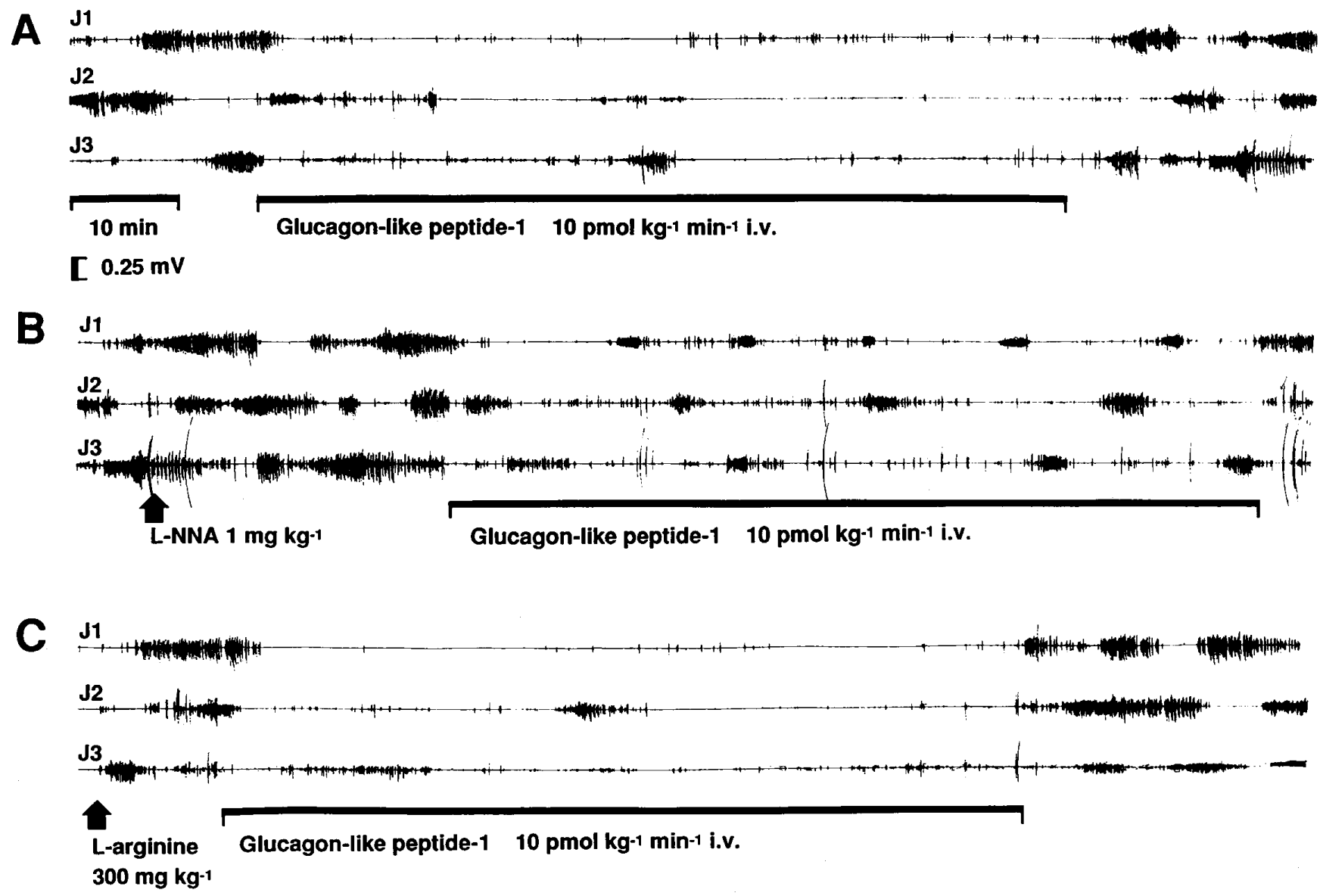

Figure 4. Continuous electromyographic recording from a rat, starting at the upper row $(A)$, passing the middle $(B)$, and terminating at the lower $(C)$, showing the MMC propagated through the jejunum at $15(\mathrm{~J} 1), 25(\mathrm{~J} 2)$, and $35(\mathrm{~J} 3) \mathrm{cm}$ distal to the pylorus. $A$ : Effect of GLP-1 alone on the MMC. $B$ : Effect of GLP-1 on the MMC after pretreatment with L-NNA given before administration of GLP-1. C: Effect of GLP-1 on the MMC after additional pretreatment with L-arginine before L-NNA. 

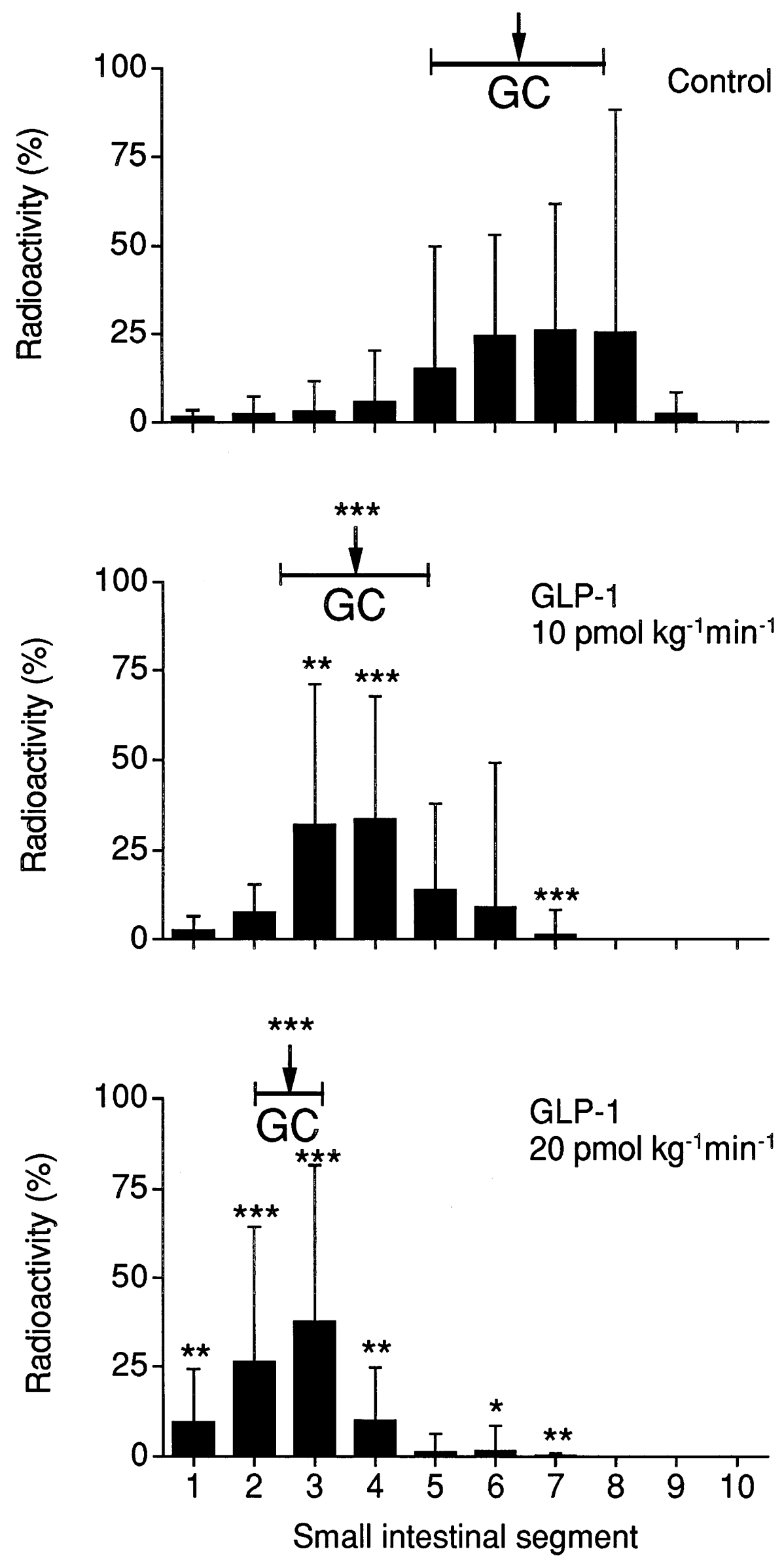

Figure 5. Distribution of the radioactive marker and calculated geometric center $(G C)$ for the marker in the small intestine after $60 \mathrm{~min}$ in control rats receiving saline $(n=9)$, and in rats receiving GLP-1 intravenously at doses of $10 \mathrm{pmol} \mathrm{kg}^{-1} \mathrm{~min}^{-1}$ $(n=8)$ and $20 \mathrm{pmol} \mathrm{kg}^{-1} \mathrm{~min}^{-1}(n=6)$. Mean values and $95 \%$ confidence interval. $* P<0.05,{ }^{*} * P<0.01,{ }^{* * *} P<0.001$. 


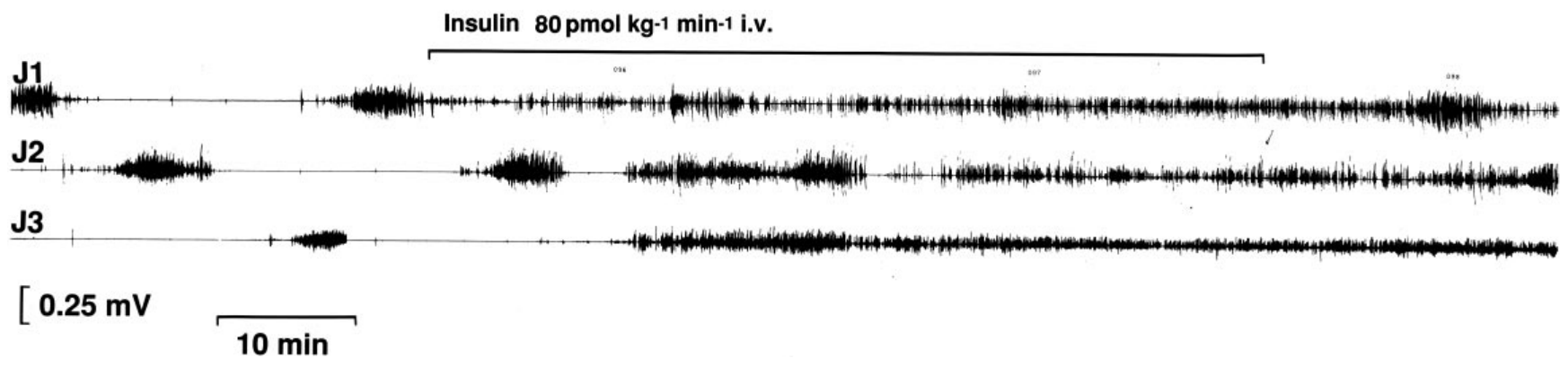

Figure 6. Electromyographic recording from the rat jejunum at $15(\mathrm{~J} 1), 25(\mathrm{~J} 2)$, and $35(\mathrm{~J} 3) \mathrm{cm}$ distal to the pylorus showing the effect of insulin on the MMC.

without affecting the basal MMC pattern $(P<0.05)$. The control MMC cycle length of $15.4 \pm 9.3,19.7 \pm 11.5$, and $20.6 \pm 10.2$ min at $\mathrm{J} 1, \mathrm{~J} 2$, and $\mathrm{J} 3$, respectively, was not significantly changed after infusion of exendin(9-39)amide alone or in combination with GLP-1. Similarly, the duration, propagation velocity, and calculated length of phase III during the infusions were not significantly changed compared to the controls above (Fig. 3).

In addition, pretreatment of the animals with L-NNA intravenously at a dose of $1 \mathrm{mg} \mathrm{kg}-1$ effectively blocked the action of GLP $10 \mathrm{pmol} \mathrm{kg}^{-1} \mathrm{~min}^{-1}$ on MMC. Thus, the recycling MMC pattern was preserved during the whole infusion period $(P<0.05)$, though with a lower amplitude. After L-NNA, the GLP-1-induced inhibition of MMC was reinstated by additional administration of L-arginine at a dose of $300 \mathrm{mg} \mathrm{kg}^{-1}$ before administration of the peptide $(P<0.05$; Fig. 4$)$.

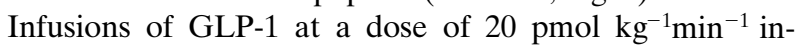
creased the plasma levels of GLP-1 from $14.7 \pm 19.7$ in controls to $77.8 \pm 54.5 \mathrm{pmol}^{-1}(P<0.01)$.

Effects of GLP-1 on transit of contents in small bowel. GLP-1 at infusions of 10 and $20 \mathrm{pmol} \mathrm{kg}^{-1} \mathrm{~min}^{-1}$ slowed the propulsion of contents through the small bowel in a dosedependent manner. This effect was verified by a progressive decrease of the geometric center for the distribution of the marker in the small bowel with increasing doses of GLP-1 $(P<0.001)$ (Fig. 5).

Effects of insulin and somatostatin on $M M C$. Insulin at a dose of 40 pmol kg-1 $\mathrm{min}^{-1}$ did not change the MMC pattern with an interval of phase III in controls of $17.9 \pm 11.4$ min at $\mathrm{J} 1$, $18.3 \pm 12.6 \mathrm{~min}$ at $\mathrm{J} 2$, and $18.8 \pm 14.5 \mathrm{~min}$ at $\mathrm{J} 3$. In addition, the characteristics of phase III in controls with a duration of $3.8 \pm 1.1,3.8 \pm 0.7$, and $3.3 \pm 1.0$ min at the $\mathrm{J} 1, \mathrm{~J} 2$, and $\mathrm{J} 3$ sites of the jejunum, a propagation velocity of $2.5 \pm 2.2$ and $1.8 \pm 1.9 \mathrm{~cm}$ $\mathrm{min}^{-1}$, as well as a calculated length of $7.6 \pm 8.5$ and $6.7 \pm 5.4$ min between the $\mathrm{J} 1$ and $\mathrm{J} 2$, and $\mathrm{J} 2$ and $\mathrm{J} 3$ sites, respectively, were not affected. At a dose of $80 \mathrm{pmol} \mathrm{kg}^{-1} \mathrm{~min}^{-1}$, the recycling MMC pattern was abolished and replaced by continuous irregular spiking during the remaining infusion period $(P<$ 0.05 ; Fig. 6). This myoelectric pattern was clearly different from that induced by GLP-1. Furthermore, at high infusion rates of $200 \mathrm{pmol} \mathrm{kg}^{-1} \mathrm{~min}^{-1}$, the animals acutely appeared more nervous and aggressive.

Insulin at a dose of $80 \mathrm{pmol} \mathrm{kg} \mathrm{kg}^{-1} \mathrm{~min}^{-1}$ increased the plasma level of insulin from control levels of 279.0 \pm 242.0 to $6600.0 \pm 6219.0 \mathrm{pmol} \mathrm{l}^{-1}(P<0.01)$, whereas the plasma levels of $\mathrm{GLP}^{-1}$ were unchanged $\left(14.7 \pm 19.7\right.$ versus $7.2 \pm 6.1 \mathrm{pmol} \mathrm{l}^{-1}$, respectively).

Somatostatin at doses of $100-500 \mathrm{pmol} \mathrm{kg}^{-1} \mathrm{~min}^{-1}$ had inhibitory effects on the MMC. At $100 \mathrm{pmol} \mathrm{kg}^{-1} \mathrm{~min}^{-1}$ the MMC cycle length was increased $(P<0.05)$ (Fig. 7). With increasing doses of somatostatin, the MMC cycle length increased in a dose-dependent manner until quiescence was induced during the whole infusion period (Fig. 8). However, the inhibitory effect of somatostatin on MMC was different from that induced by GLP-1 and appeared more irregularly. The characteristics of phase III during infusion of somatostatin were not different from those observed during the control period, except for a slightly shorter duration of phase III seen at $\mathrm{J} 1$ with the highest dose of somatostatin $(2.2 \pm 1.4 \mathrm{~min}$; $P<0.05)$. Under control conditions, the duration of phase III of MMC was $3.7 \pm 0.9,3.7 \pm 1.2$, and $3.5 \pm 1.4 \mathrm{~min}$ at the $\mathrm{J} 1$, $\mathrm{J} 2$, and $\mathrm{J} 3$ sites of jejunum, the propagation velocity $1.5 \pm 1.0$ and $1.9 \pm 0.7 \mathrm{~cm} \mathrm{~min}^{-1}$, and the calculated length $5.2 \pm 2.8$ and $6.9 \pm 2.5$ min between the $\mathrm{J} 1$ and $\mathrm{J} 2$, as well as the $\mathrm{J} 2$ and $\mathrm{J} 3$ sites, respectively. The general condition of the rats was not affected by somatostatin.

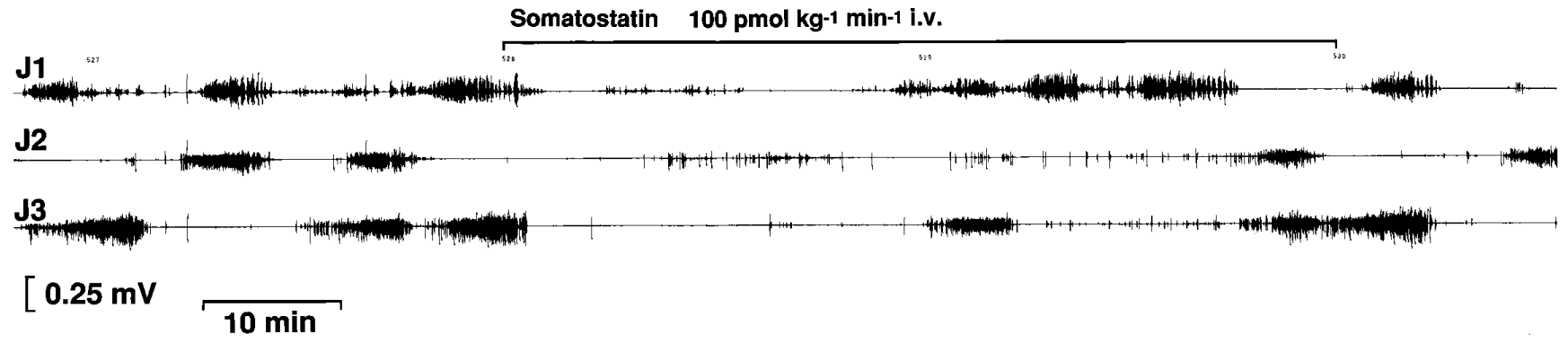

Figure 7. Electromyographic recording from the rat jejunum at 15 (J1), 25 (J2), and 35 (J3) cm distal to the pylorus showing the effect of somatostatin on the MMC. 


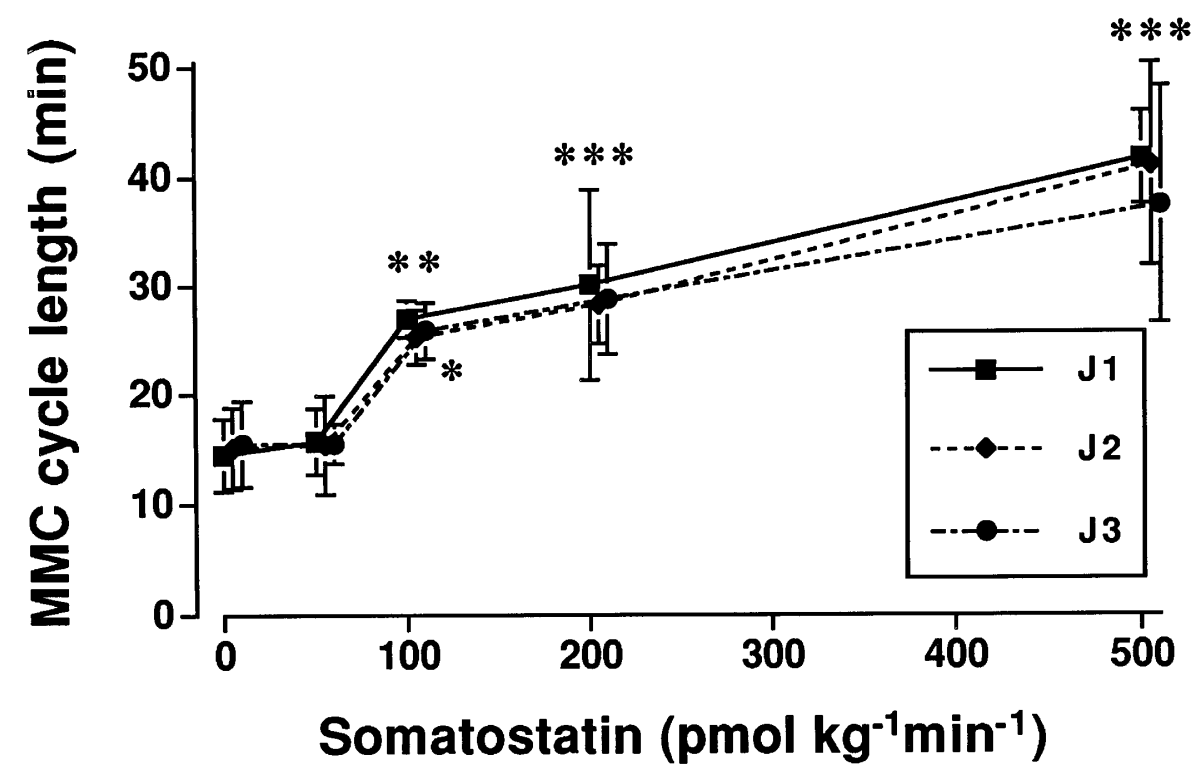

Figure 8. Dose-response curve showing the effect of increasing doses of somatostatin on the cycle length of the MMC at three different levels in the rat jejunum, 15 (J1), $25(\mathrm{~J} 2)$, and $35(\mathrm{~J} 3) \mathrm{cm}$ distal to the pylorus. $* P<0.05, * * P<0.01$ and $* * * P<0.001$. Mean values and $95 \%$ confidence interval $(n=7)$.
Pretreatment of the rats with L-NNA at a dose of $1 \mathrm{mg}$ $\mathrm{kg}^{-1}$ intravenously failed to block the inhibitory action of somatostatin $500 \mathrm{pmol} \mathrm{kg}^{-1} \mathrm{~min}^{-1}$ on the recycling MMC pattern $(P<0.01)$. This effect was different compared to that obtained with GLP-1 in combination with L-NNA and L-arginine (Fig. 9).

Infusion of somatostatin $100 \mathrm{pmol} \mathrm{kg} \mathrm{km}^{-1} \mathrm{~min}^{-1}$ increased basal plasma somatostatin levels from $17.5 \pm 9.1 \mathrm{pmol}^{-1}$ to $5213.5 \pm 2770.0 \mathrm{pmol} \mathrm{l}^{-1}(P<0.01)$, whereas the plasma levels of GLP-1 were not significantly changed (14.7 \pm 19.7 versus $3.7 \pm 2.0 \mathrm{pmol} \mathrm{l}^{-1}$, respectively).

Effect of GLP-1 on circulating levels of insulin, somatostatin, and glucose. During infusions of GLP-1 at doses of 20 or

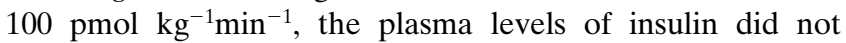
change, and the blood glucose levels were unaffected. However, during the infusions of GLP-1, the plasma levels of somatostatin increased significantly in a dose-dependent manner $(P<0.01)$ (Table I).

\section{Studies of the fed motor pattern}

After food intake the fasted motor pattern was disrupted and replaced by a fed motor pattern with irregular spiking at all recording sites in the intestinal segment under study.

Effects of GLP-1 and exendin(9-39)amide on fed myoelectric activity. Intravenous infusion of GLP-1 at doses of 20 and $40 \mathrm{pmol} \mathrm{kg}^{-1} \mathrm{~min}^{-1}$ inhibited the irregular spiking seen after food intake. At a dose of $20 \mathrm{pmol} \mathrm{kg}^{-1} \mathrm{~min}^{-1}$ the irregular spiking was attenuated from $14.0 \pm 6.5$ to $3.2 \pm 3.0$ spikes $10 \mathrm{~s}^{-1}$ at $\mathrm{J} 1$, from $11.8 \pm 5.7$ to $3.8 \pm 1.9$ at $\mathrm{J} 2$, and from $12.1 \pm 6.8$ to $4.1 \pm 2.9$ at $\mathrm{J} 3$ (each $P<0.01$; Fig. 10). At $40 \mathrm{pmol} \mathrm{kg}^{-1} \mathrm{~min}^{-1}$ the irregular spiking was almost completely abolished with

Table I. Effect of Glucagon-like Peptide-1 on Circulating Levels of Insulin, Somatostatin, and Glucose

\begin{tabular}{lccc}
\hline \multicolumn{1}{c}{ Infusion } & $\begin{array}{c}\text { P-Insulin } \\
\left(\mathrm{pmol} \mathrm{l}^{-1}\right)\end{array}$ & $\begin{array}{c}\text { P-Somatostatin } \\
\left(\mathrm{pmol} \mathrm{l}^{-1}\right)\end{array}$ & $\begin{array}{c}\text { B-Glucose } \\
\left(\mathrm{mmol} \mathrm{l}^{-1}\right)\end{array}$ \\
\hline Saline & $279.0 \pm 242.0$ & $4.6 \pm 3.5$ & $7.8 \pm 1.7$ \\
GLP-1 $\left(20 \mathrm{pmol} \mathrm{kg}^{-1} \mathrm{~min}^{-1}\right)$ & $370.0 \pm 318.2$ & $9.2 \pm 7.6$ & $6.7 \pm 1.3$ \\
GLP-1 $\left(100 \mathrm{pmol} \mathrm{kg}^{-1} \mathrm{~min}^{-1}\right)$ & $239.8 \pm 281.0$ & $24.8 \pm 25.8 * *$ & $8.6 \pm 2.6$
\end{tabular}

Mean values and $95 \%$ confidence interval $(n=6) . * * P<0.01$. only some scattered spikes during the infusion period, calculated to $1.5 \pm 0.6,1.9 \pm 1.0$, and $2.4 \pm 1.4$ spikes $10 \mathrm{~s}^{-1}$ at $\mathrm{J} 1, \mathrm{~J} 2$, and $\mathrm{J} 3$, respectively (each $P<0.01$ ).

The inhibitory action of GLP-1 at $20 \mathrm{pmol} \mathrm{kg} \mathrm{kmin}^{-1}$ on fed myoelectric activity was not affected by pretreatment with L-NNA at a dose of $1 \mathrm{mg} \mathrm{kg}^{-1}$. Compared to control experiments with GLP-1 alone at the same dose, the spiking activity remained constant at the $\mathrm{J} 1, \mathrm{~J} 2$, and $\mathrm{J} 3$ levels with computed values of $9.4 \pm 4.3,8.4 \pm 3.2$, and $8.1 \pm 3.9$ spikes $10 \mathrm{~s}^{-1}$, respectively.

In contrast, pretreatment with exendin(9-39)amide intravenously at a dose of $1,000 \mathrm{pmol} \mathrm{kg}^{-1} \mathrm{~min}^{-1}$ stimulated the myoelectric response after food intake. Compared to food alone, the spiking activity at the $\mathrm{J} 1$ level increased from $13.5 \pm 4.3$ to 17.9 \pm 4.5 spikes $10 \mathrm{~s}^{-1}$ and at $\mathrm{J} 2$ from $12.9 \pm 4.4$ to $18.8 \pm 5.9$ spikes $10 \mathrm{~s}^{-1}$ (both $\mathrm{P}<0.05$ ). At the $\mathrm{J} 3$ level only a modest increase of spiking activity from $12.0 \pm 6.8$ to $14.6 \pm 5.5$ spikes 10 $\mathrm{s}^{-1}$ was noted (Fig. 11).

Effect of food intake on circulating levels of GLP-1. After food intake, the circulating levels of GLP-1 increased. $30 \mathrm{~min}$ after feeding, the plasma level of GLP-1 was found to be $33.5 \pm 16.2$ pmol $1^{-1}$, with maximal values amounting to 54 pmol $1^{-1}$. In control rats the plasma level of the peptide was $11.8 \pm 9.3 \mathrm{pmol} \mathrm{l}^{-1}(P<0.01)$.

\section{Discussion}

The naturally occurring gut peptide GLP-1 is secreted from L-cells in the distal ileum and has prominent effects on the endocrine pancreas and glucose metabolism. GLP-1 is an important incretin, i.e., a humoral factor from the intestinal tract, which at physiological concentrations potentiates the glucoseinduced insulin release (22).

Motility of the small intestine is easiest to investigate under fasting conditions because of the presence of a motor pattern that can be predicted to recur within certain intervals, i.e., the MMC with phase I, phase II, and the prominent phase III, which exhibits a maximal contractile activity for that part of the intestine. After food intake, however, the motility pattern changes to a hitherto mathematically undefined pattern of irregular spiking activity all over the small intestine.

Intravenous infusions of GLP-1 at doses as low as $10 \mathrm{pmol}$ 

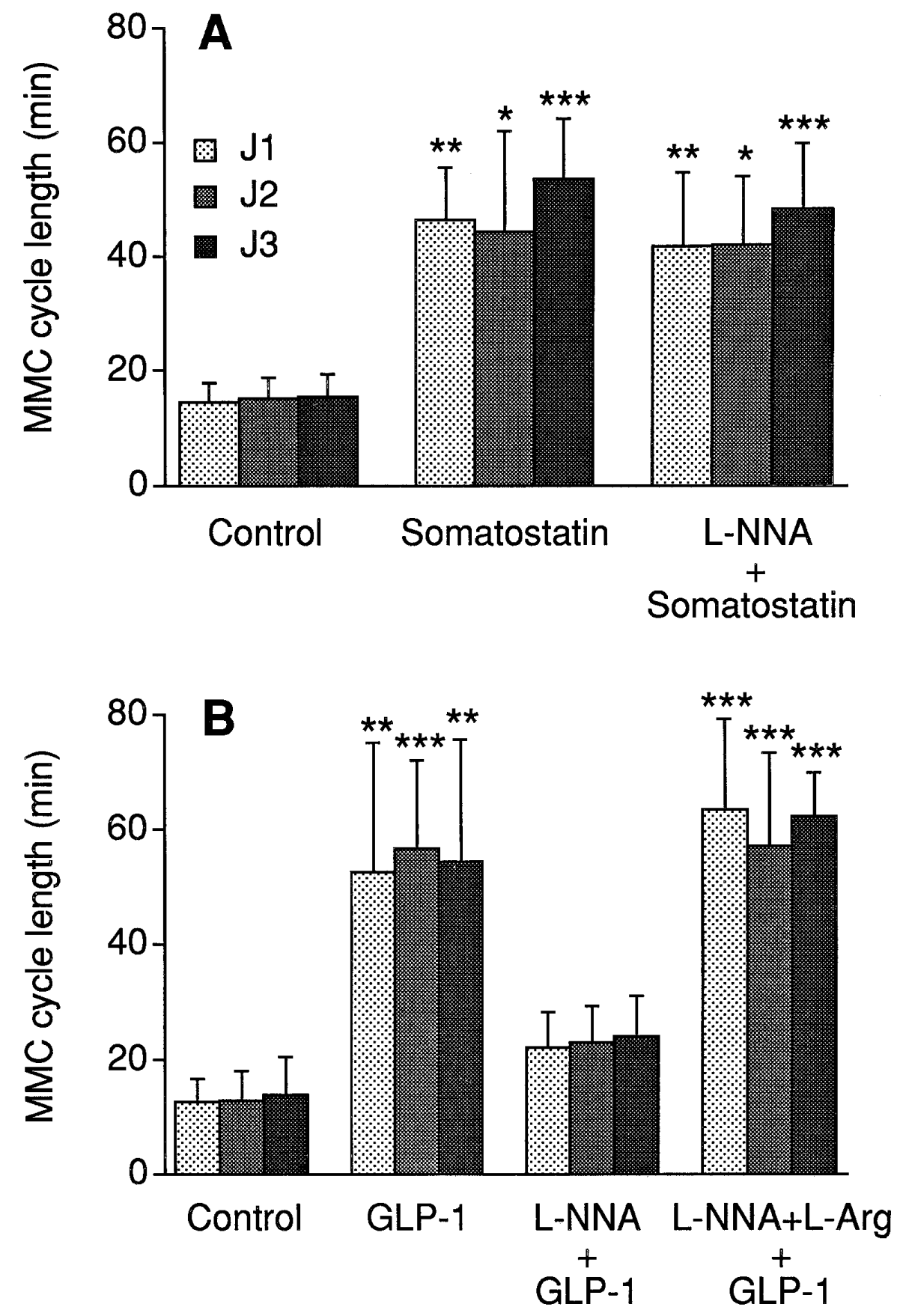

Figure 9. Composite diagram of the effect of the nitric oxide/L-arginine pathway on the response to somatostatin and GLP-1 on the cycle length of the MMC. $A$ : Effect somatostatin $\left(500 \mathrm{pmol} \mathrm{kg}^{-1} \mathrm{~min}^{-1}\right)$ alone and after pretreatment with L-NNA (1 mg $\left.\mathrm{kg}^{-1}\right)(n=8) . B$ : Effect of GLP-1 (10 pmol $\mathrm{kg}^{-1} \mathrm{~min}^{-1}$ i.v.) alone, and after pretreatment with L-NNA ( $1 \mathrm{mg} \mathrm{kg}^{-1}$ i.v. $)$, as well as L-arginine ( $L$-Arg) $\left(300 \mathrm{mg} \mathrm{kg}^{-1}\right.$ i.v. $)$ in combination with L-NNA ( $1 \mathrm{mg} \mathrm{kg}^{-1}$ i.v. $)$ $(n=6)$. Mean values and $95 \%$ confidence interval. $* P<0.05, * * P<0.01$, and $* * * P<$ 0.001 .

$\mathrm{kg}^{-1} \min ^{-1}$ disrupted the MMC and induced myoelectric quiescence in a dose-dependent manner. Concomitantly, the transit of contents in the small intestine was inhibited in a similar fashion. This effect is well in agreement with our earlier studies in the rat showing that replacing the MMC by myoelectric quiescence slows propulsion through the gut $(21,23)$, and should also be valid for the replacement of fed myoelectric by quiescence, as irregular spiking has been considered to promote a substantial propulsion through the gut $(24,25)$, whereas quiescence does not (21). The effect of GLP-1 on MMC and transit was substantiated by calculation of the geometric center for the distribution of the intestinal marker, which provides a robust measure of the transit rate (20).

At infusion rates of GLP-1 up to $20 \mathrm{pmol} \mathrm{kg}^{-1} \mathrm{~min}^{-1}$, the plasma concentrations reached were within or close to the physiological range as shown in our present experiments in the rat and in previous work in man (26). The relatively higher dosage required in rats to achieve similar plasma concentrations as in humans can be explained by the fact that the clearance rate of GLP-1 is 10-20 times higher in rats than in man (27). It is reasonable to use a higher infusion rate of the peptide in rats to achieve comparable plasma concentrations as in humans. In addition, the inhibitory motor response to GLP-1 was abolished by pretreatment with the GLP-1 receptor antagonist exendin(9-39)amide (28). Commensurate with this, exendin(9-39)amide used as a GLP-1 receptor antagonist has been shown to reduce the incretin effect in rats challenged with an intraduodenal glucose load (29), and hence, exendin(9- 

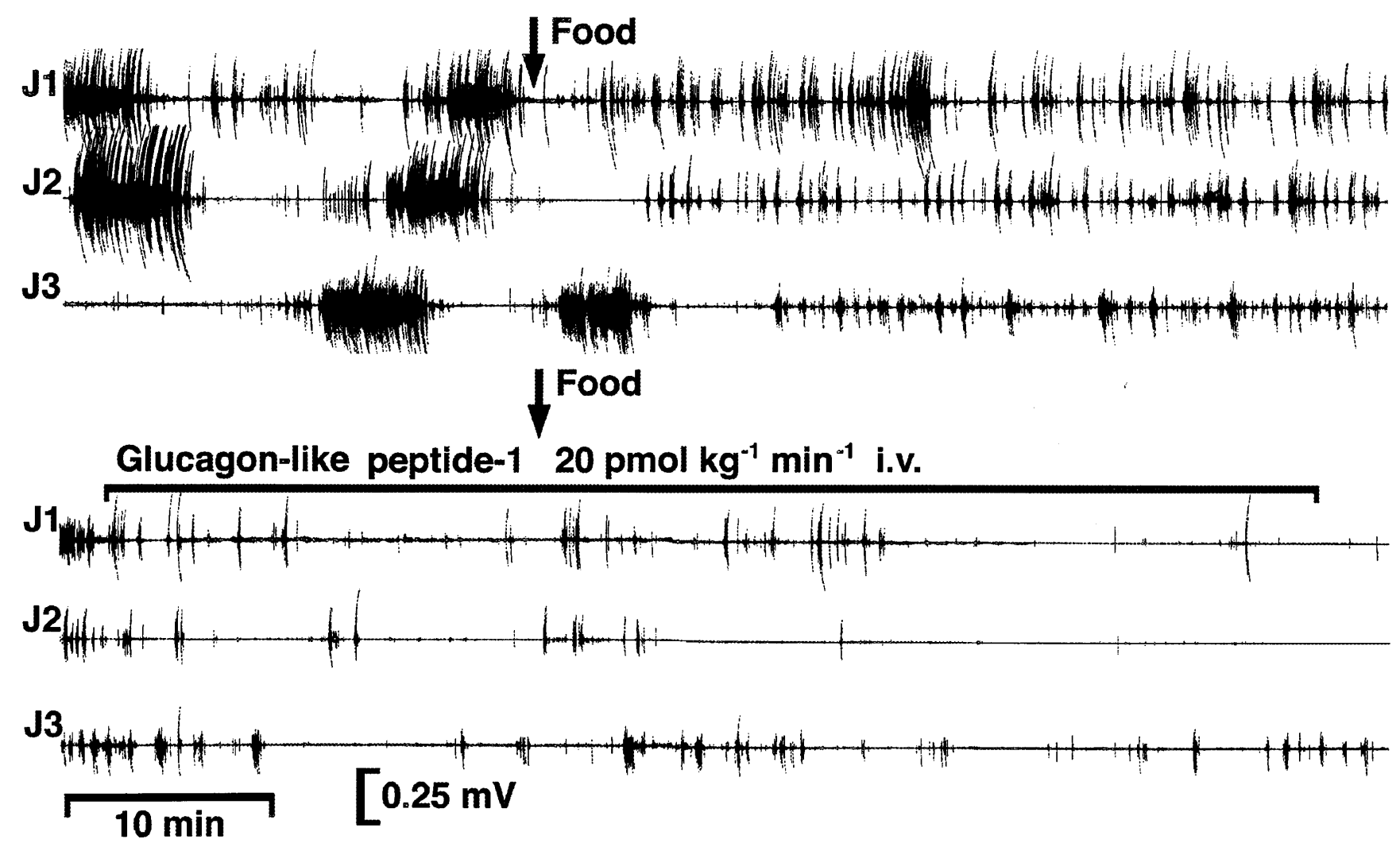

Figure 10. Electromyographic recording from the rat jejunum at $15(\mathrm{~J} 1), 25(\mathrm{~J} 2)$, and $35(\mathrm{~J} 3) \mathrm{cm}$ distal to the pylorus showing the effect of food intake alone (top) and after pretreatment with GLP-1 (bottom) in the same animal.

39)amide was considered a useful GLP-1 receptor antagonist for in vivo studies. Thus, our findings point in favor of a receptor-mediated mechanism for a physiological inhibition of GLP-1 on the MMC.

The effect of GLP-1 on MMC was clearly distinguishable from that of insulin, which induced irregular spiking similar to that seen after food intake $(19,30)$. Also, somatostatin disrupted the MMC and induced quiescence in a different manner to that of GLP-1, provided that the peptide was administered at high doses causing supraphysiological plasma concentrations. Therefore, it seems most likely that the inhibitory effect of GLP-1 on the MMC pattern is directly mediated by GLP-1 on the motility-regulating systems of the gut, and not via a hormonal release of insulin or somatostatin.
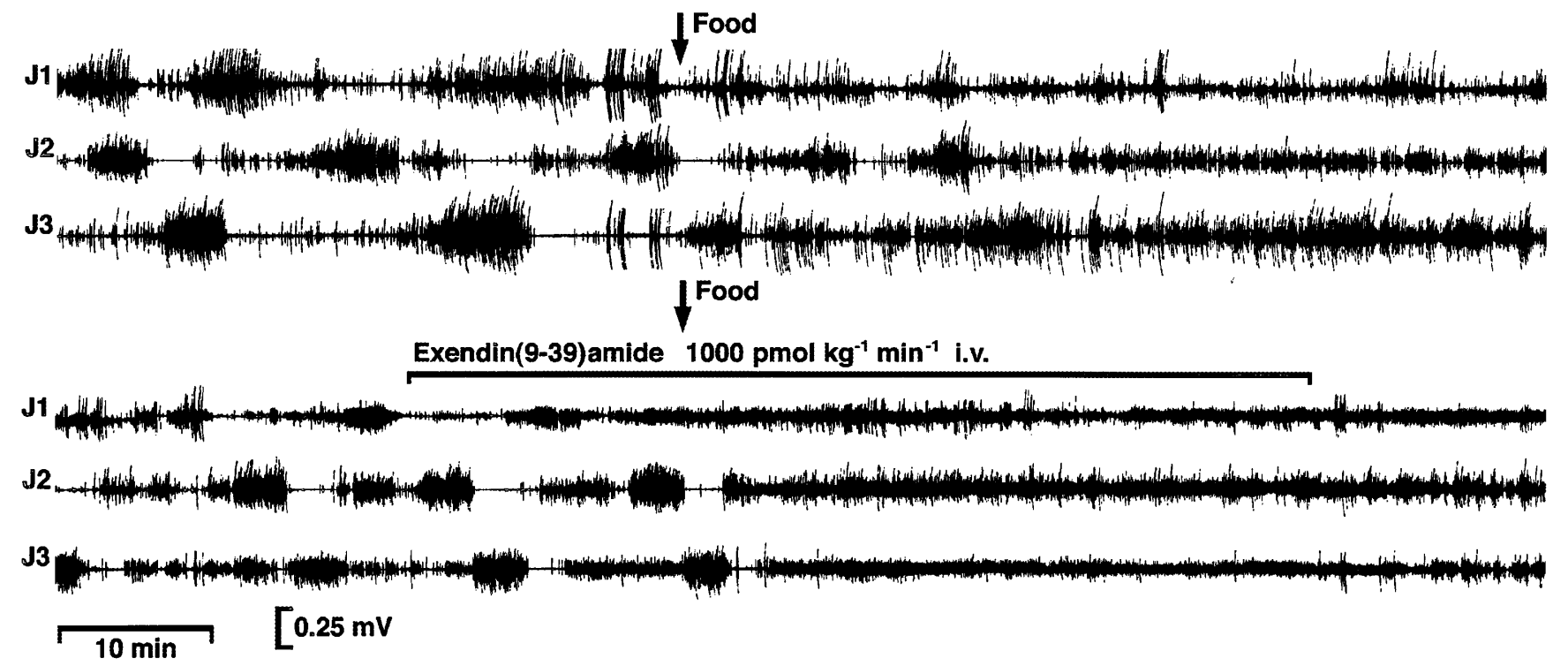

Figure 11. Electromyographic recording from the rat jejunum at $15(\mathrm{~J} 1), 25$ (J2), and 35 (J3) cm distal to the pylorus showing the effect of food intake alone (top) and after pretreatment with exendin(9-39)amide (bottom) in the same animal. 
Because the inhibitory response of GLP-1 on MMC was blocked by treatment with the NO synthase inhibitor L-NNA, and as this effect was possible to revert by additional treatment with L-arginine at a high dose, it seems likely that the inhibitory effect of GLP-1 on MMC is dependent on the elaboration and release of NO in the enteric nervous system or smooth muscle. Alternatively, in support of this, earlier studies indicate a close relationship between relaxatory responses of the gut and NO $(31,32)$, especially the MMC $(33,34)$, where also the action of vasoactive intestinal peptide has been shown to be involved (35). The possibility of an unspecific inhibition of the effect of GLP-1 secondary to a blood pressure increase after L-NNA seems less likely, as L-NNA does not affect the inhibition of motility caused by other peptides, such as vasoactive intestinal peptide (35).

In addition to its inhibitory effects on the MMC, GLP-1 was shown to block the fed myoelectric pattern in the rat. This effect of the peptide seemed to require somewhat higher doses than the inhibition of the fasting myoelectric pattern and could not be shown to be dependent on NO. However, such a finding is not very surprising, as a host of different gastrointestinal peptides are considered to cooperate in the stimulation of motility after food intake. In line with an inhibitory action of GLP-1 on fed motility, we found that the GLP-1 receptor antagonist exendin(9-39)amide modestly increased the motility response to food intake. Because the array of gastrointestinal peptides released after food intake all work through distinct receptor mechanisms mainly to stimulate postprandial motor activity, it is not very likely that one single peptide with an inhibitory receptor, such as GLP-1, should be of vital importance for the regulation of postprandial motility.

The results from other studies indicate that GLP-1 exerts weak insulin-releasing properties at euglycemia $(6,12)$. In our present study, however, GLP-1 did not stimulate insulin release even at doses as high as $100 \mathrm{pmol} \mathrm{kg}^{-1} \mathrm{~min}^{-1}$. Thus, during postabsorptive conditions, motility of the gastrointestinal tract seems to be considerably more sensitive to GLP-1 as compared to responses of pancreatic $\beta$ cells.

GLP-1 has also been found to stimulate somatostatin release in rat pancreatic cell cultures (10), and in both the perfused pig and dog pancreas (36). In contrast to insulin release, GLP-1 markedly stimulates somatostatin release also at low glucose levels (9). Similarly, in our experiments GLP-1 at 100 pmol kg-1 $\mathrm{min}^{-1}$ markedly enhanced somatostatin, but not insulin, release. However, the release of somatostatin to peripheral blood was obtained at doses of GLP-1 higher than those required to inhibit the MMC. In addition, in other species such as dog (37) and man (38), somatostatin has been shown to stimulate premature $\mathrm{MMC}$, which is different from the rat. This supports our conclusion that the inhibitory effect of GLP-1 on motility under physiological circumstances is not mediated by a release of somatostatin. In this context, it is of interest that the insulin-stimulating effect of GLP-1, both in the amidated and nonamidated form, has been shown to be glucosedependent $(8,39-41)$. Therefore, our results using fasted rats for hormone release experiments may not be representative for postprandial conditions when GLP-1 may simultaneously influence both gastrointestinal motility and hormonal responses. Furthermore, the finding that the inhibitory action of somatostatin on the MMC was not affected by L-NNA strengthens our conclusion that the effect of GLP-1 on motility is not mediated by somatostatin, neither as a circulating hormone nor as a local mediator at the intestinal level.
Taken together, it seems that GLP-1 acts directly on gastrointestinal motor functions to cause an inhibition of motility. Such an effect may be of great importance for the preabsorptive delivery of nutrients to the intestine via a slowed propulsion through the gut. A decreased absorption rate of nutrients is considered beneficial to decrease the requirements of insulin to maintain normoglycemia. In support of this view, Gutniak and co-workers (26) have found that meal-related insulin requirements and plasma insulin levels after GLP-1 infusion in both insulin-dependent and non-insulin-dependent diabetic patients are greatly reduced. Hence, speculations have been made that GLP-1 may act as a novel treatment for diabetes mellitus, especially in non-insulin-dependent diabetes mellitus $(42,43)$. We believe that these mechanisms, together with the inhibition of gastrointestinal motility, involving also gastric emptying, play an important role for the marked antidiabetogenic effect of GLP-1 demonstrated in patients with NIDDM and IDDM. In support of such an antidiabetogenic mechanism, Nauck and collaborators have recently found the inhibitory action of GLP-1 on gastric emptying to outweigh its insulinotropic effect in healthy humans (44).

Interestingly enough, a number of peptide hormones from the proximal small intestine that have been considered as incretin candidates not only release insulin from the pancreas, but also inhibit gastrointestinal motility, mainly gastric emptying. Such an effect should diminish insulin requirements in relation to food intake. This double effect is obvious for gastric inhibitory peptide, which, however, has a lower insulin-releasing capacity than GLP-1 $(7,45)$ and inhibits gastric emptying only at supraphysiological plasma concentrations (46). Another incretin candidate with similar properties is cholecystokinin, which releases insulin upon food intake $(47,48)$ and causes slowing of gastric emptying at physiological plasma levels (49). Thus, even if earlier findings implicate that the inhibitory actions on gastrointestinal motility by various incretins may be attributed to a common pathway through their ability to release insulin to the circulation, our present data show that the inhibitory action of GLP-1 on gastrointestinal motility in the rat is not mediated via insulin, because the motor pattern after administration of GLP-1 was clearly different from that obtained with insulin. Therefore, it seems most likely that GLP-1, and possibly other incretin candidates, such as gastric inhibitory peptide and cholecystokinin, inhibit gastrointestinal motor activity by distinct mechanisms acting directly on enteric neurons or smooth muscle cells, separate from the insulin-releasing mechanisms in the pancreas. As an alternative explanation for its effects on motility, GLP-1 may be released to act as a humoral afferent link with effects on the circumventricular organs, such as area postrema, in the brain. Thus, vagal nonadrenergic noncholinergic mechanisms could be stimulated, resulting in NO release and inhibition of motility.

In conclusion, the inhibitory effect of GLP-1 on gastrointestinal motility seems neither to be mediated via insulin nor somatostatin, but instead through direct mechanisms acting directly in the enteric nervous system or on smooth muscle cells partly dependent on the L-arginine/NO pathway.

\section{Acknowledgments}

The study was supported by the Swedish Medical Research Council (No. 7916), Magnus Bergvall's foundation, Professor Nanna Svartz' foundation, Fredrik and Ingrid Thuring's foundation and Åke 
Wiberg's foundation. This work was conducted as part of a collaboration between Addis Ababa University, Faculty of Medicine, and the Karolinska Institutet, and was supported by Swedish Agency for Research Cooperation with Developing Countries (SAREC) (grant No. S2/ETI 12).

\section{References}

1. Mojsov, S., G. Heinrich, I.B. Wilson, M. Ravazzola, L. Orci, and J.F. Habener. 1986. Preproglucagon gene expression in pancreas and intestine diversifies at the level of posttranslational processing. J. Biol. Chem. 261:11880-11886.

2. Novak, U., A. Wilks, G. Buell, and S. McEven. 1987. Identical mRNA for preproglucagon in pancreas and the gut. Eur. J. Biochem. 164:553-557.

3. Ørskov, C., J.J. Holst, S. Knuhtsen, F.G.A. Baldissera, S.S. Poulsen, and O.V. Nielsen. 1986. Glucagon-like peptides GLP-1 and GLP-2, predicted products of the glucagon gene, are secreted separately from the pig small intestine, but not pancreas. Endocrinology. 119:1467-1475.

4. Holst, J.J. 1988. Enteroglucagon. Adv. Metab. Dis. 11:392-419.

5. Ørskov, C., J.J. Holst, S.S. Poulsen, and P. Kirkegaard. 1987. Pancreatic and intestinal processing of proglucagon in man. Diabetologia. 30:874-881.

6. Holst, J.J., C. Ørskov, O.V. Nielsen, and T.W. Schwartz. 1987. Truncated glucagon-like peptide I, an insulin-releasing hormone from the distal gut. FEBS Lett. 211:169-174.

7. Kreymann, B., M.A. Ghatei, G. Williams, and S.R. Bloom. 1987. Glucagon-like peptide-1 7-36: a physiological incretin in man. Lancet. ii:1300-1303.

8. Mojsov, S., G.C. Weir, and J.F. Habener. 1987. Insulinotropin: glucagonlike peptide-I (7-37) co-encoded in the glucagon gene is a potent stimulator of insulin release in the perfused rat pancreas. J. Clin. Invest. 79:616-619.

9. Ørskov, C., J.J. Holst, and O.V. Nielsen. 1988. Effect of truncated glucagon-like peptide-1 (proglucagon-(78-107) amide) on endocrine secretion from pig pancreas, antrum, and non-antral stomach. Endocrinology. 123:2009-2013.

10. d'Alessio, D.A., W.Y. Fujimoto, and J.W. Ensinck. 1989. Effects of glucagonlike peptide I-(7-36) on release of insulin, glucagon, and somatostatin by rat pancreatic islet cell monolayer cultures. Diabetes. 38:1534-1538.

11. Wettergren, A., B. Schjoldager, P.E. Mortensen, J. Myhre, J. Christiansen, and J.J. Holst. 1993. Truncated GLP-1 (proglucagon 78-107-amide) inhibits gastric and pancreatic functions in man. Dig. Dis. Sci. 38:665-673.

12. Gutniak, M.K., L. Juntti-Berggren, P.M. Hellström, A. Guenifi, J.J. Holst, and S. Efendic. 1996. Glucagon-like peptide I enhances the insulinotropic effect of glibenclamide in NIDDM patients and in the perfused rat pancreas. Diabetes Care. 19:857-863.

13. Grill, V., J. Pigon, S.G. Hartling, C. Binder, and S. Efendic. 1990. Effects of dexamethasone on glucose-induced insulin and proinsulin release in low and high insulin responders. Metabolism. 39:251-258.

14. Grill, V., M. Gutniak, A. Roovete, and S. Efendic. 1984. A stimulating effect of glucose on somatostatin release is impaired in noninsulin-dependent diabetes mellitus. J. Clin. Endocrinol. Metab. 59:293-297.

15. Ørskov, C., L. Rabenhø, A. Wettergren, H. Kofod, and J.J. Holst. 1994. Tissue and plasma concentrations of amidated and glycine extended glucagonlike peptide-1 in humans. Diabetes. 43:535-539.

16. Deacon, C.F., A.H. Johnsen, and J.J. Holst. 1995. Degradation of glucagon-like peptide- 1 by human plasma in vitro yields an $\mathrm{N}$-terminally truncated peptide that is a major endogenous metabolite in vivo. J. Clin. Endocrinol. Metab. 80:952-957.

17. Hjelm, M., and C. de Verdier. 1963. A methodological study of the enzymatic determination of glucose in blood. Scand. J. Clin. Lab. Invest. 15:415-428.

18. Hellström, P.M., R.O. Bränström, and A. Al-Saffar. 1993. Computer program "MMC" to summarize characteristics of activity fronts of migrating myoelectric complex in rat small intestine. Surg. Res. Commun. 14:51-63.

19. Bränström, R., and P.M. Hellström. 1996. Characteristics of fasting and fed myoelectric activity in rat small intestine: evaluation by computer analysis. Acta Physiol. Scand. 158:53-62.

20. Miller, M.S., J.J. Galligan, and T.F. Burks. 1981. Accurate measurement of intestinal transit in the rat. J. Pharmacol. Methods. 6:211-217.

21. Hellström, P.M., and C. Johansson. 1989. Neuropeptide Y inhibits the migrating myoelectric complex and delays small intestinal transit in man. $J$. Gastrointest. Mot. 1:35-41.

22. Zunz, E., and J. La Barre. 1929. Contributions à l'étude des variations physiologiques de la sécrétions externe et interne du pancreas: relation entre les sécrétions externe et interne du pancreas. Arch. Int. Physiol. Biochim. 31:20.

23. Al-Saffar, A., P.M. Hellström, and G. Nylander. 1985. Correlation between peptide YY-induced myoelectric activity and transit of small-intestinal contents in rats. Scand. J. Gastroenterol. 20:577-582.

24. Al-Saffar, A., P.M. Hellström, G. Nylander, and S. Rosell. 1984. Influence of fasting and bombesin-induced myoelectric activity on the transit of small-intestinal contents in the rat. Scand. J. Gastroenterol. 19:541-546.

25. Lördal, M., C. Johansson, and P.M. Hellström. 1993. Myoelectric pattern and effects on small bowel transit induced by the tachykinins neurokinin A, neurokinin B, substance $\mathrm{P}$ and neuropeptide $\mathrm{K}$ in the rat. J. Gastrointest. Mot. 5:33-40.

26. Gutniak, M.K., C. Ørskov, J.J. Holst, B. Ahrén, and S. Efendic. 1992 Antidiabetogenic effect of glucagon-like peptide-1 (7-36)amide in normal subjects and in patients with diabetes mellitus. N. Engl. J. Med. 326:1316-1322.

27. Holst, J.J. 1991. Degradation of pancreatic peptides: glucagon. In Degradation of Bioactive Substances, Physiology and Pathophysiology. Uniscience volume. J.H. Henriksen, editor. CRC Press, Boca Raton, FL. 139-149.

28. Raufman, J.P. 1996. Bioactive peptides from lizard venoms. Regul. Pept. 61:1-18

29. Kolligs, F., H.C. Fehmann, R. Göke, and B. Göke. 1995. Reduction of the incretin effect in rats by the glucagon-like peptide-1 receptor antagonist exendin (9-39) amide. Diabetes. 44:16-19.

30. Ruckebusch, M., and J. Fioramonti. 1975. Electrical spiking activity and propulsion in small intestine in fed and fasted rats. Gastroenterology. 68:1500-1508.

31. Bult, H., G.E. Boeckxstaens, P.A. Pelckmans, F.H. Jordaens, Y.M. van Maercke, and A.G. Herman. 1990. Nitric oxide as an inhibitory non-adrenergic non-cholinergic neurotransmitter. Nature. 345:346-347.

32. Iversen, H.H., N.P. Wiklund, and L.E. Gustafsson. 1994. Nitric oxidelike activity in guinea pig colon as determined by effector responses, bioassay and chemiluminescence analysis. Acta Physiol. Scand. 152:315-322.

33. Sarna, S.K., M.F. Otterson, R.P. Ryaqn, and V.E. Cowles. 1993. Nitric oxide regulates migrating motor complex cycling and its postprandial disruption. Am. J. Physiol. 265:G759-G766.

34. Rodriguez-Membrilla, A., V. Martinez, M. Jimenez, E. Gonalons, and P. Vergara. 1995. Is nitric oxide the final mediator regulating the migrating myoelectric complex cycle? Am. J. Physiol. 268:G207-G214.

35. Hellström, P.M., and T. Ljung. 1996. Nitrergic inhibition of migrating myoelectric complex in the rat is mediated by vasoactive intestinal peptide. Neurogastroenterol. Mot. 8:299-306.

36. Kawai, K., S. Suzuki, S. Ohashi, H. Mukai, H. Ohmori, Y. Murayama, and K. Yamashita. 1989. Comparison of the effects of glucagon-like peptide1-(1-37) and -(7-37) and glucagon on islet hormone release from isolated perfused canine and rat pancreases. Endocrinology. 124:1768-1773.

37. Hostein, J., J. Janssens, G. Vantrappen, T.L. Peeters, M. Vandeweerd, and G. Leman. 1984. Somatostatin induces ectopic activity fronts of the migrating motor complex via a local intestinal mechanism. Gastroenterology. 87:1004 1008 .

38. von der Ohe, M., P. Layer, C. Wollny, J.W. Ensinck, T.L. Peeters, C. Beglinger, and H. Goebell. 1992. Somatostatin 28 and coupling of human interdigestive intestinal motility and pancreatic secretion. Gastroenterology. 103: 974-981.

39. Shima, K., M. Hirota, and C. Ohboshi. 1988. Effect of glucagon-like peptide-1 on insulin secretion. Regul. Pept. 22:245-252.

40. Komatsu, R., T. Matsuyama, M. Namba, N. Watanabe, H. Itoh, N Kono, and S. Tarui. 1989. Glucagonostatic and insulinotropic action of glucagonlike peptide I-(7-36)-amide. Diabetes. 38:902-905.

41. Gefel, D., G.K. Hendrick, S. Mojsov, J.F. Habener, and G.C. Weir. 1990. Glucagon-like peptide-1 analogues: effects on insulin secretion and adenosine 3'5'-monophosphate formation. Endocrinology. 126:2164-2168.

42. Nauck, M.A., J.J. Holst, and B. Willms. 1997. Glucagon-like peptide 1 and its potential in the treatment of non-insulin-dependent diabetes mellitus. Horm. Metab. Res. 29:411-416.

43. Nauck, M.A., J.J. Holst, B. Willmas, and W. Schmiegel. 1997. Glucagonlike peptide 1 (GLP-1) as a new therapeutic approach for type 2-diabetes. Exp. Clin. Endocrinol. Diabetes. 105:187-195.

44. Nauck, M.A., U. Niedereichholtz, R. Ettler, J.J. Holst, C. Ørskov, R. Ritzel, and W.H. Schmiegel. 1997. Glucagon-like peptide 1 inhibition of gastric emptying outweighs its insulinotropic effects in healthy humans. Am. J. Physiol. 273:E981-E988.

45. Kreymann, B., M.A. Ghatei, V. Schusdziarra, S.R. Bloom, and M. Classen. 1990. Does the incretin effect exist for GIP or GLP-1 7-36 amide at physiological glucose concentrations in man? Digestion. 46(Suppl. 1):59.

46. Brown, J.C., J.R. Dryburgh, S.A. Ross, and J. Dupré. 1975. Identification and actions of gastric inhibitory polypeptide. Recent Prog. Horm. Res. 31: 487-532.

47. Szecowka, J., P.E. Lins, and S. Efendic. 1982. Effects of cholecystokinin, gastric inhibitory polypeptide, and secretin on insulin and glucagon secretion in rats. Endocrinology. 110:1268-1272.

48. Rushakoff, R.J., I.D. Goldfine, J.D. Carter, and R.A. Liddle. 1987. Physiological concentrations of cholecystokinin stimulate amino acid-release in humans. J. Clin. Endocrinol. Metab. 65:395-401.

49. Schang, J.C., and K.A. Kelly. 1981. Inhibition of canine interdigestive proximal gastric motility by cholecystokinin octapeptide. Am. J. Physiol. 240: G217-G220. 